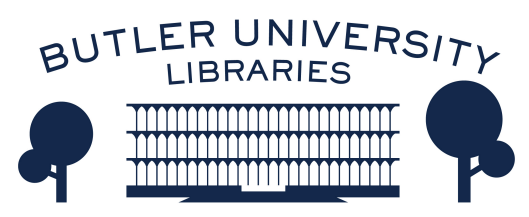

Journal of Hindu-Christian Studies

Volume 16

Article 7

January 2003

\title{
Swami Abhishiktananda's Interreligious Hermeneutics of the Upanishads
}

Edward T. Ulrich

Follow this and additional works at: https://digitalcommons.butler.edu/jhcs

Part of the Religion Commons

\section{Recommended Citation}

Ulrich, Edward T. (2003) "Swami Abhishiktananda's Interreligious Hermeneutics of the Upanishads," Journal of Hindu-Christian Studies: Vol. 16, Article 7.

Available at: https://doi.org/10.7825/2164-6279.1296

The Journal of Hindu-Christian Studies is a publication of the Society for Hindu-Christian Studies. The digital version is made available by Digital Commons @ Butler University. For questions about the Journal or the Society, please contact cbauman@butler.edu. For more information about Digital Commons @ Butler University, please contact digitalscholarship@butler.edu. 


\title{
Swami Abhishiktananda's Interreligious Hermeneutics of the Upanishads
}

\author{
Edward T. Ulrich \\ University of St. Thomas
}

SWAMI

ABHISHIKTANANDA

(Henri Le Saux,1910-1973) was a French monk who came to India in 1948 to establish an "inculturated" form of Christian monasticism, a monasticism which would not simply reflect a European heritage but would be truly Indian in character. Engaged in this project, he had many profound encounters and experiences with Indian life and culture. These led him to become greatly enamored of the Upanishads and to enter their spiritual world. Yet he maintained his identity as a Catholic priest and strove to integrate the Upanishads with Christianity. To this end he frequently read the Bible and the Upanishads side-by-side.

Abhishiktananda's approach to this interreligious reading is most clearly articulated in Hindu-Christian Meeting Point, a book which developed out of a 1963 meeting Nagpur of various Christian friends and associates at Nagpur. During this week long event the Bible and the Upanishads were prayerfully read in alternating sessions. The Bible was read first in the day to serve as an entry point into the Upanishads. Abhishiktananda explained: "It is precisely his practice of reading the holy Scriptures and recognizing the inspiration of the Spirit in the writings of prophets and apostles ... that has made him [the Christian] capable of recognizing the voice of God in everything." Sensitized to the Spirit of God through the Bible, one may hear the voice of God in the Upanishads.

Though the Bible is the entry point for the Christian, one must not project one's Christian ideas onto the Upanishads but should be genuinely attentive to their message: "He [the Christian] must first of all listen to the witness of this experience itself, trying to make himself totally transparent to it, to assimilate himself to it as deeply as possible."2 After listening carefully to the Upanishads the Christian is to return to the Bible, integrating one's newly gained perspective with one's original perspectives. Hence, the concluding two sessions of the meeting consisted of readings from the Gospel of John and discussions of these readings and the Upanishads in light of each other. This paper will illustrate the two aspects of Abhishiktananda's hermeneutic, which are his entry into the Upanishads and his attempts at integration with Christianity, by examining both his personal journey in India and the proceedings of the Nagpur meeting.

\section{Entry into the Upanishads}

Abhishiktananda was raised in a pious Catholic family and was deeply inspired by Christian ideals and goals. In fact, he

Edward Ulrich is an Assistant Professor in the Department of Theology at the University of St. Thomas in Minnesota. His research interests include the theology of religions, monastic interreligious dialogue, and the comparative study of Vedanta and Western thought. He is working on a project examining current theologies of religious pluralism in light of the interaction between Roman religion and Christianity in the early centuries of the common era. 
entered the minor seminary at Châteaugiron at age eleven and the Benedictine monastery of St. Anne's in Kergonan at age nineteen. ${ }^{3}$ Before entering the cloister, the young man contemplated the harshness this life: "Poverty ... must at times be a heavy burden. I like to have things of my own, to have things which in some sense complete my ' $I$ ', but in the monastery I have to feel that none of the things that I use belongs to me."4 Through communal living and obedience to the abbot the Benedictine monk learns humility and self-abnegation. The goal is to thereby submit one's self-will to the will of Christ. ${ }^{5}$ Although a very difficult goal, Abhishiktananda was highly enthusiastic about it: "The richness of monastic life I have only begun to glimpse now that I have entered it for good; and I still feel myself as if inundated, dazzled by it; it is too vast for one to be able to grasp it all at once." $" 6$

Within five years of having entered the monastery, Abhishiktananda became disappointed with St. Anne's and desired a more rigorous expression of Benedictine monasticism. Hence, in 1948, after a total of nineteen years at St. Anne's, he settled in Tamil Nadu with the permission of his abbot. Three years later, with the permission of the local bishop, Abhishiktananda and another French priest, Jules Monchanin, established the Benedictine monastery of Shantivanam near the village of Kulittalai. ${ }^{7}$ Their aim was to "lead the contemplative life, in the absolute simplicity of early Christian monasticism and at the same time in the closest possible conformity with the traditions of Indian samnyasa [monasticism]." In this goal they were inspired by the ideal of "inculturation," of living Christian faith in conformity with local traditions, an ideal which had been emphasized in the writings of recent popes. ${ }^{9}$ To establish a monastery which would express both Christian religion and Indian life, Abhishiktananda made deep forays into Tamil culture, including three visits from 1949 to 1951 to Ramana Maharshi's ashram at Tiruvannamalai. This man had a reputation in both India and Europe as a spiritual master and a great ascetic, and so Abhishiktananda was very excited to meet him. About his first visit he wrote, "I concentrated on looking with deep attention at this man, of whom I had read and heard so much. This visit could not fail to be a high point in my life." first visit was sitting in the presence of the Maharshi, receiving his darsh or "sight." On subsequent visits Abhishiktananda also conversed with Ramana's disciples, visited the nearby holy mountain of Arunachala, and carefully observed the life and activities of the ashram. ${ }^{11}$

Abhishiktananda's understanding of the Upanishads underwent a profound transformation in conjunction with these visits to Sri Ramanasram. In Europe he had received a Christian education which placed strong emphasis on the distinction between God and the soul. Contrasting with this, the Upanishads teach that the atman (self) is Brahman (Immense Being), that the deepest part of oneself coincides with ultimate reality. From teachings such as this Abhishiktananda had concluded, while a monk in Europe, that Hinduism is riddled through with pantheism. ${ }^{12}$

However, in classical Advaitic exegesis the atman does not refer to individual souls which are subsequently merged with the divine. Rather, it refers to the substratum of consciousness which underlies individual awareness. Abhishiktananda began to realize this meaning of the term through discussions with Ramana's disciples. For instance, during his second visit in 1949 he was taught that the atman is "deep within oneself, beyond ... . all the fleeting identifications of what one is with what one has or what one does." 1952, four months after his third visit to Ramana's ashram, he no longer regarded the Upanishads as pantheistic but referred in his diary to the atman as the subtle presence of God in all things, the "Self of one's Self, ..., the very one who resides in the most 
intimate depths of each created being: men, animals, plants, the sun, stars."14

As discussed above, Abhishiktananda would later write in Meeting Point that it is one's Christian formation which serves as an entry point into the Upanishads, for this formation may render one sensitive to their spiritual message. Indeed, it was the overlap between Benedictine and Advaitic spiritualities which had guided Abhishiktananda to India and to sit at the feet of the Maharshi. Even more specifically, the Benedictine ideal of selfabnegation served as a steppingstone towards accepting the Advaitic concept of the dissolution of individuality. As he had written in February 1952,

Deep contacts with Hindu thought, books and people. Even before I came here, they had already made a mark on me. A hidden spiritual sympathy [with Advaitins], this sense of the Unity, of the ONE, of God at the source of my being, of the fading out of this 'ego' as soon as you penetrate into the interior of yourself so as to reach the unique ' $I$ '. 15

From 1952 to 1955, Abhishiktananda pursued this newly understood ideal by spending seven periods of residence at the holy mountain of Arunachala, near Sri Ramanasram. There he lived like the other Hindu ascetics at the mountain, regulating his life by solitude, begging, and silence. ${ }^{16}$ This lifestyle helped him find immersion in interior levels of consciousness: "It is as if each day of silence was drawing you ever further and further from all familiar ways. . . the mind is freed from those external reminders with which it is assaulted in every moment of its ordinary life." ${ }^{.17}$ The mountain, too, which has been associated with Advaitic realizations in the local mythology, promoted detachment: "This world which I have left once, a second time, / and once again, finally and for good, for you- / erase it from my being ... In silence you teach me silence, O Arunachala." 18

In order to continue pursuing this experience, Abhishiktananda engaged in many periods of intensive Upanishadic study, especially from 1962 to $1973 .{ }^{19} \mathrm{He}$ generally approached this through the lens of Ramana's philosophy, evident for instance, in his discussion of the epiphany of Brahman in the Kena Upanishad. Ramana had emphatically stressed that the power of thought belongs to Brahman alone, not to individual intellects. In the Kena Upanishad, Brahman appeared as a specter to the Vedic deities, who, according to Abhishiktananda, represent the physical, subtle, and mental energies of the human being. ${ }^{20}$ The gods could not comprehend this specter and they lost their powers when they approached it. After their humiliation the goddess Uma appeared and explained that the apparition was Brahman, later referred to in the Upanishad as Tad, "That."21 " The significance, according to Abhishiktananda, is that "nothing in the cosmos or in man has power, energy or effectiveness apart from That $[\mathrm{Tad}]$, the one who is the source of all power and who is at work in every activity, whether cosmic or human.",22

Though the Upanishads point to the reality of Brahman, their main purpose is not to rationally inform one of Brahman's existence or to impart ideas about it. Rather, they promote experiences of Brahman by shocking the normal flow of consciousness: In them everything-words, the order of words, the sequence or non-sequence of ideas-is aimed ... a at shattering the accepted categories of perception and judgement in which we normally make ourselves at home. ... The effect is like subtle but powerful waves, conveyed by the words, the images, the symbols, even the harshness of style and the disconcerting shifts to different levels of the macrocosm (the universe) and the microcosm (man). ${ }^{23}$

Abhishiktananda probably had in mind passages such as the following: "As vast as the space here around us is this space within the heart, and within it are contained both the earth and the sky, both fire and wind, both the sun and the moon. ${ }^{24}$ Here, without any,-justification or argument, the minute 
space within the heart is equated with the vast stretches of the universe. Stunned by contemplating this paradoxical equation, one's normal mental processes may be suspended, just as the powers of the gods were suspended in the Kena Upanishads. This suspension allows an awareness of the underlying substratum of consciousness to emerge.

\section{Integration with Christianity}

- The foundation of Benedictine monasticism is the ascetical example of Jesus Christ. It was this example which, ultimately, had led Abhishiktananda into the Upanishads. However, he believed that Christ had left behind a testimony very different from that of the Advaitic sages. Like the Upanishads, Christ had reported unity with his heavenly Father, but he had also reported an absolute distinction: "The experience of the Absolute to which India's mystical tradition bears such powerful witness is all included in Jesus' word: 'My Father and I are one'. . . . And yet, at the very heart of all this, there remains the 'face-to-face' of the Son and the Father. ${ }^{, 25}$ The Christian theological tradition has developed Jesus' joint reports of unity and distinction into the doctrine of the Trinity. The Father and the Son share the same divine substance, but they are distinct in that the Father is the eternal source from which the Son receives his being. The Holy Spirit, in turn, is the reciprocal exchange of love and communion between the Father and the Son.

Abhishiktananda carefully attended to the differing testimonies of the Gospels and the Upanishads by reading them side-byside, especially during the last decade of his life $^{.26}$ A good example of his approach to this were discussions at the 1963 Nagpur meeting which focused on the Biblical Logos and the Upanishadic Tad. While the Kena Upanishad concludes with the revelation of Brahman as Tad, "That," the true power in the cosmos, the Gospel of John begins by introducing Jesus Christ as the Logos, the Word of God. The meeting participants noted important similarities between the two principles, but also important differences.

The similarity is that both principles are portrayed as permeating the cosmos. This overlap helped the meeting attendees to appreciate the Upanishads and to enter their spiritual world. ${ }^{27}$ Yet, the difference is that the Logos has been classically regarded as the source of reason and order in the cosmos, as something that can be apprehended by the intellect, whereas $\mathrm{Tad}$ is a pronoun which conveys minimal information about its referent. The Upanishads designate supreme reality by this term because Brahman lies beyond all thought. Abhishiktananda explained: "In the East, when thought discovers that which is transcendent, it refuses to reason about or name this Beyond. All it will say is 'That is it, Tad.' Certainly it is supreme Bliss; it is a lightning-flash; but nothing more can be said., 28

Introduced to God as Tad by the Upanishads, the Christian returns to the Bible with a new perspective. Abhishiktananda claimed that at the meeting participants found the essential concept of Tad present in John 1:1, "The Word [Logos] was God [Theos]."29 This is an odd expression in Greek, for John was using neither the substantive ho Theos nor the adjectival theios. In the former case he would have been asserting an identity between the Logos and God, whereas in the latter case he would have been affirming the Logos as a divine entity of lesser status. Scholars debate whether John was indicating an identity or whether he was cutting a middle path between the two possibilities. ${ }^{30}$

Abhishiktananda believed that John was doing neither of these. Rather, he was pointing to a reality which exceeds the categories of thought and reason, something about which little can be conveyed. In other words, John was pointing to the same reality indicated by the Tad of the Upanishads: "The expression he uses is not theios, 
divine, not ho theos, 'the' God, the Unique; but theos without the article, God who is called by the same name as the Unique, and yet is other than the Unique. . . , the Logos seems to be ...., the 'That' of which the rishis [seers] had an intuition"

This gives the Christian a new way of seeing the Gospel. The early church had developed a relatively clear and fixed doctrine of the Trinity which resolves the ambiguities in John by accounting for both identity and difference in the Godhead. However, the purpose of John's Gospel is not to present conundrums to be intellectually solved but words and images to transform the reader. Like the Upanishads, the Gospel invites one to enter the heart of the divine itself. The Upanishads can help the contemporary Christian to appreciate this facet of the Gospel and to be transformed by it. In language evoking his earlier spiritual experiences at Arunachala, Abhishiktananda explained that when the Upanishads are read conjointly with John they "will allow nothing to remain of that superficial bodily, or at best merely mental, ego which belongs to the level of concepts. It will never allow us to rest content with anything less than the ' $I$ ' which God utters within himself, in the mysterious [trinitarian] procession of Word and the Spirit."32

The Christian who has undergone this encounter with Hinduism will not only see the Bible differently but also the Upanishads. Immediately before the mysterious "Word was God" statement, John states that "the Word was with God."33 This, according to some exegetes, implies unmistakable difference: "The Greek preposition translated with suggests the idea of communion. The thought is lit. 'towards God', which requires some distinctiveness between God and the Word." 34 This, in turn, connotes the dynamic exchange of substance between the Father and the Son in trinitarian doctrine. Hence, through the Bible the Christian knows that there is a fundamental distinction at the heart of the Upanishadic
Tad, a term which otherwise implies a reality beyond the realm of difference and categories. $^{35}$

This means that the Upanishads can be meditated on in new ways. Traditional Upanishadic predicates of the divine include Sat, Cit, and Ananda (Being, Consciousness, Bliss), which imply the self-existence, selfawareness, and inherent joy of Brahman. Abhishiktananda believed that when the Upanishads are read alongside the Gospel of John a relationship of love and communion is revealed at the heart of Brahman. Sat and Cit may be regarded, for instance, as shared between two centers: the Father and the Son. The Father emanates Being and Consciousness while the Son receives it. Ananda hence indicates not simply the joy of unlimited Being but of shared Being: "He [Son] and I [Father] love each other in the very fullness of our Bliss-the supreme revelation of ANANDA, the Bliss of Being." ${ }^{36}$ In this way the Christian might prayerfully read the Upanishads through the lens of the Gospels.

\section{Conclusion}

Abhishiktananda's interreligious hermeneutics of the Upanishads center on two poles: a deep receptivity to Advaita and a strong fidelity to Christianity. A critical turning point in his openness came when he accepted some of the basic teachings of Ramana, Maharshi's philosophy. After making this step he did not focus on expanding his knowledge of the philosophy of Advaita. Rather, he prayerfully read the Upanishads over and over with the same themes in mind, allowing the words and images to impact his mind. Simultaneous with this he was reading the Christian scriptures, allowing the two worlds to interact in profound ways.

The importance of repetitiously reading the Upanishads can be seen by examining the writings of Shankara, the classic Advaitic commentator. In his BrahmaSutra-Bhashya he had insisted that different 
Upanishadic meditations cannot be combined into a single master account. Francis Clooney concludes from this that the primary purpose of the Bhashya is not to yield a theoretical system but to promote a continuous rereading of different Upanishadic texts in light of each other. The aim of such study is to realize "Brahman in a radical revision of our own identities.",37 One can best accomplish this, Clooney argues, through participation in the exegetical tradition of Shankara and his successors.

In sharp contrast to Clooney, Abhishiktananda largely avoided Shankara, feeling that the complexities of his exegesis are unnecessary for the modern reader. ${ }^{38} \mathrm{He}$ even suggested that this commentarial tradition erected a system of thought in place of the experiential approach of the Upanishads. ${ }^{39}$ Clooney and Abhishiktananda disagree in their evaluation of Shankara, but they both conclude that the Upanishads are meant to be continuously reread in order to promote a transforming encounter with reality. Further, they both argue that not only should the Advaitic aspirant submit to this process, but that the would-be Christian comparativist should do so as well. Such study will enable the comparativist to see and experience the Christian mystery in new and different ways. ${ }^{40}$

\section{Notes}

1. Abhishiktananda, HinduChristian Meeting Point: Within the Cave of the Heart, rev. ed., trans. Sara Grant (Delhi: ISPCK, 1976), p. 31.

2. Ibid.

3. James Stuart, Swami Abhishiktananda: His Life Told through His Letters (Delhi: ISPCK, 1989), pp. 1-6.

4. Abhishiktananda to novicemaster, 4 December 1928, ibid., p. 3 .
5. Adalbert de Vogüé, Community and Abbot in the Rule of St Benedict, trans. Charles Philippi, Cistercian Studies, no. 5.1 (Kalamazoo: Cistercian Publications, 1979), p. 236.

6. Abhishiktananda to R. Macé, 27 October 1929, in Stuart, Swami Abhishiktananda, p. 6.

7. Stuart, Swami Abhishiktananda, pp. 12-13, 38-40.

8. Abhishiktananda to J. Mendonça, 15 May 1947, ibid., p. 13.

9. For a discussion of these papal writings see Aylward Shorter,

Toward a Theology of Inculturation (Maryknoll, NY: Orbis, 1988), pp. 179-86.

10. Abhishiktananda, The Secret of Arunachala, (Delhi: ISPCK, 1979), p. 4.

11. Ibid., pp. 9-23.

12. "This [pantheism] is the error par excellence of Hinduism, which places the supreme good [of man] in an absorption into God." Abhishiktananda, "Amour et Sagesse," typewritten document, Abhishiktananda Archives, Vidyajyoti College of Theology, Delhi, p. 23. See also Abhishiktananda to J. Monchanin, 18 August 1947, in Stuart, Swami Abhishiktananda, p. 18.

13. Abhishiktananda, Secret, p. 14.

14. Idem, Guhantara, typewritten document, Abhishiktananda Archives, Vidyajyoti College of Theology, Delhi, 37. For a discussion relation between this essay and the March 1952 diary entry see Stuart, Swami Abhishiktananda, p. 64. 
15. Abhishiktananda to J. Lemarié, 10 February 1952, in Stuart, Swami Abhishiktananda, p. 59.

16. Accounts of his stays at the mountain are spread through Abhishiktananda, Secret of Arunachala, 19-136; idem, Ascent to the Depth of the Heart: The Spiritual Diary (1948-1973) of Swami Abhishiktananda (Dom H.Le Saux), trans. David Fleming and James Stuart, ed. Raimon Panikkar (Delhi: ISPCK, 1998), pp. 25-131; Stuart, Swami Abhishiktananda, pp. 60-97.

17. Abhishiktananda, Secret, p. 30.

18. Abhishiktananda, diary entry, p. 6 April 1952, Ascent, p. 37. See also Skanda Purana 1.3.U.16.23.

19. Stuart, Swami Abhishiktananda, pp. 176-78, 202-203, 219-20, 232, 294-300, 302-303, 308, 311-12, 324, 334.

20. Abhishiktananda, Meeting Point, rev. ed., pp. 51-52.

21. Kena 4.6. See also Brihadaranyaka 2.3.1-5; 3.9.9; Taittiriya 2.6.

22. Abhishiktananda, Meeting Point, rev. ed., p. 52. For other examples of how he approached the Upanishads through Ramana's philosophy see Abhishiktananda, ibid., pp. 5458; idem, "The Upanishads and the Advaitic Experience" Clergy Monthly 38 (1974): 476-82; idem, The Further Shore: Two Essays by Abhishiktananda: "Sannyasa" and "The Upanishads-An Introduction" (Delhi: ISPCK, 1975), pp. 63-65

23. Idem, Meeting Point, rev. ed., pp. 47-48. See also idem, diary entry, 28 May 1972, Ascent, p. 351; ibid., 30 May 1972, pp.
353-54; ibid., 31 May 1972, p. 355; Abhishiktananda to $\mathrm{R}$. Vachon, 8 March 1970, in Stuart, Swami Abhishiktananda, p. 254; ibid., Abhishiktananda to O. Baumer-Despeigne, 28 May 1972, pp. 300-301; ibid., Abhishiktananda to Marc Chaduc, 28 May 1972, p. 302; ibid., 9 June 1972, p. 304; idem, Further Shore, pp. 59-64.

24. Chandogya (trans. Patrick Olivelle in Upanishads, Oxford World's Classics, Oxford: Oxford University Press, 1996), 8.1.3.

25. Abhishiktananda,

Saccidananda: A Christian Approach to Advaitic Experience (Delhi: ISPCK, 1974), p. 82. Abhishiktananda was aware of the theism of the Upanishads and of Ramana Maharshi. See ibid., p. 81; idem, Meeting Point, rev. ed., p. 46; idem, Further Shore, p. 70; Abhishiktananda to Marc Chaduc, 13 June 1972, in Stuart, Swami Abhishiktananda, p. 304.

26. See n. 19.

27. Abhishiktananda, Meeting Point, rev. ed., pp. 59-60.

28. Ibid., p. 57. Cf. Raimundo Panikkar, ed. and trans., The Vedic Experience (Berkeley: University of California Press, 1977), p. 894; Olivelle, trans., Upanishads, 312.

29. John 1.1 (NAB).

30. Raymond Brown, The Gospel According to John (i-xii), vol. 29, The Anchor Bible (Garden City, NY: Doubleday, 1966), pp. 5, 24-25.

31. Abhishiktananda, Meeting Point, rev. ed., p. 80. See also idem, diary entry, 29 March 1964, Ascent, p. 267; Henri Le 
Saux, Intériorité et Révélation: Essais théologiques, Le Soleil dans le Cour, ed. M.-M. Davy (Sisteron, France: Presence, 1982), p. 282.

32. Abhishiktananda, Meeting Point, rev. ed., p. 97.

33. John 1:1 (NAB). (Italics added.)

34. Donald Guthrie, "John," in New

Bible Commentary: 21st Century Edition, fourth ed., (Downers Grove: Inter-Varsity Press, 1994), p. 1025. Abhishiktananda's discussion of this point focuses on John 17, not John 1:1, but the available exegesis supports his thesis.

35. Abhishiktananda felt that the diversity in cultures and peoples help one to plunge more deeply into the mysteries of the Christian scriptures. He did not believe he was discovering anything in John of which the author was not already aware. Abhishiktananda, Meeting Point, rev. ed., p. 77.

36. Abhishiktananda, Meeting Point, rev. ed., p. 88. (The original, poetic form of this passage was modified for insertion into the current text.)

37. Francis X. Clooney, Theology after Vedanta: An Experiment in Comparative Theology (New York, NY: State University of New York Press, 1993), p. 78. See also ibid., pp. 18-23, 33-35, 64-68.

38. Abhishiktananda, Further Shore, pp. 66-67.

39. Abhishiktananda to Marc Chaduc, 26 June 1972, in Stuart, Swami Abhishiktananda, pp. 306-307; ibid., 11 April 1973, p. 329.

40. Clooney, Theology after Vedanta, pp. 153-56. 